\title{
ヒト・レトロウイルスのトランスアクチベーション機構
}

\section{本来は複製の制御機構か? ATLなどの発症機構の解明にも期待}

レトロウイルスは mRNA をゲノムとしてもつ. ウイ ルス感染後, 細胞内に入り达んだ mRNA はウイルスが もつ逆転写酵素 (reverse transcriptase) により cDNA に変換され，宿主細胞のゲノムに組み込まれる．これが プロウイルスと呼ばれる状態で, ウイルスゲノムは宿主 ゲノムと同じ挙動を示す. 通常, レトロウイルスは, gag (核タンパク), pro (プロテアーゼ), pol (逆転写酵 素), $e n v$ (外膜タンパク) の各遺伝子を基本単位として もっている. 基本単位の両端に LTR (long terminal repeat）と呼ばれる調節領域があり, LTR を境にして宿 主細胞ゲノムに組み込まれる. LTR の内部はさらに $\mathrm{U} 3, \mathrm{R}, \mathrm{U} 5$ ( $5^{\prime} \rightarrow 3^{\prime}$ 方向) に分けられる.

感染細胞でウイルスが産生される際には, プロウイ ルスゲノムから mRNA が新たに合成される.この合 成反応には宿主細胞の転写装置が使われる. ウイルス mRNA は $5^{\prime}$ 側の LTR 中のRの上端 (5' 端) から始ま り, $3^{\prime}$ 側 LTR のRの下端で終わる. LTR 中の U 3 に はプロモーターがあり, さらにその上流にェンハンサー が同定されているものが多い.

ヒトのレトロウイルスは 1980 年代になり初めて発見 された. HTLV-I (human T-cell leukemia virus type I) と HIV (human immunodeficiency virus) であ る(1,2). いずれも疾病にかかわるウイルスで, HTLV-I は成人 T 細胞白血病 (ATL), HIV は AIDS の原因ウイ ルスとされている. 両ウイルスともへルパー $\left(\mathrm{CD} 4^{+}\right)$ T細胞を主な 感染宿主細胞としているが， HTLV-I は $\mathrm{T}$ 細胞を腫瘍化して 無限増殖させるのに対し, HIV は 最終的にT細胞を殺してしまう。
HTLV-I は生体で ATL をひき起こし, in vitro で正 常 T細胞をトランスホームする発癌性レトロウイルスで ある. 動物の発癌性レトロウイルスには癌遺伝子(vonc)をもつものが多く, 活性型の癌遺伝子を細胞に持ら 込むことによって癌化をひき起こす。，一部癌遺伝子をも たないものは細胞側癌遺伝子 (c-onc) の近傍にプロウ イルスが入り达んで細胞側癌遺伝子を活性化し, 癌化を 誘導する. HTLV-I は, プロウイルスの組み达み部位が 一定して括らず, 典型的な癌遺伝子ももっていない.し たがって，今までのレトロウイルスによる発癌機構とは 異なる機構で細胞を癌化させていると考えられている. HTLV-I は基本単位の遺伝子の他に $\mathrm{pX}$ と呼ばれる領域 をもつ.この領域からは 2 種類の核タンパク ( $40^{\operatorname{tax}}$ と

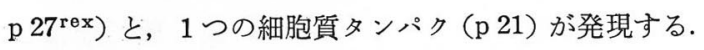
$\mathrm{pX}$ 遺伝子は典型的な癌遺伝子ではないが, これらの産 物と細胞癌化との関連が注目されている(3).

当初, HTLV-I の LTR はHTLV-I 産生細胞ではプ ロモーター活性を示すが, HTLV-I 非産生細胞ではプ ロモーター機能が発揮でさないことが観察された. その 後, LTR のプロモーター活性に必要な HTLV-I 発現の 中味は p 40tax であることが判明し, HTLV-I の発現 は自分自身の産物 (p $\left.40^{\operatorname{tax}}\right)$ によって転写レベルで調節 されていることが明らかになった. p 40tax によるこの トランスアクチベーションは LTR の U 3 領域中の TATA ボックス上流にあるエンハンサーを介して行な われる.このエンハンサーの中には, 不完全であるが 21 bp 配列が 3 回登場するダイレクト・リピートがあり, この $21 \mathrm{bp}$ 配列が $\mathrm{p} 40^{\mathrm{tax}}$ のトランスアクチペーシ ヨンの標的配列となる. HTLV-I エンハンサーは他のウイルスのトラ ンスホーミング遺伝子 (adenovirus E $1 \mathrm{~A}$ 遺伝子, bovine papilloma virus E 2 遺伝子）によっても活性 化される。

採取直後の ATL 細胞には HT-

レトロウイルスの遺伝子構造 
LV-I に由来する抗原の発現がみられない. 試験管内で 2,3 日培養するとウイルスの遺伝子産物が発現してく る. このことは, HTLV-I のエンハンサーは誘導型で, p $40^{\operatorname{tax}}$ 以外にもエンハンサーを活性化するものがある 可能性を示している. 実際, 免疫刺激やプロテインキナ ーゼCのアクチベーターである TPA（12-O-tetradecanoylphorbol-13-acetate), 細胞内 cAMP 濃度を上昇 させる forskolin で細胞を処理することによりェンハン サー活性を誘導することができる. TPA による誘導はエ ンハンサー中の $21 \mathrm{bp}$ 配列のみでは不充分で, 他に標的 配列があるものと思われる. $21 \mathrm{bp}$ 内には CRE (cAMP responsible element) と同じ塩基配列があり, forskolin はこの配列を介してェンハンサーを活性化する. しか し, p $40^{\operatorname{tax}}$ が必要とする塩基配列と CRE とは完全に は一致しない，合成 CRE は forskolin には反応するが p 40tax には反応しない. p 40tax の標的配列は CRE を 含むもっと長い配列が必要なようである. 合成 $21 \mathrm{bp}$ 配 列に結合する核タンパクは, HTLV-I 感染の有無によら ず細胞間で差がみられず, p $40^{\mathrm{tax}}$ は直接 $21 \mathrm{bp}$ 配列に 結合しないだろうと考えられている.

HTLV-I に感染した T 細胞はインターロイキン 2 ( T 細胞増殖因子, IL-2) の受容体を恒常的に発現する ようになる. 本来, IL-2 受容体は免疫反応の際, $\mathrm{T}$ 細胞 が増殖するとき一過性に発現する. ATL 細胞の IL-2 受容体の異常発現が ATL 発症の 1 つの, 特に初期過程 の, ステップとして重要と考えられている.この発現は $\mathrm{p} 40^{\operatorname{tax}}$ のトランスアクチベーションの結果とされてい る. 実験系では, IL-2 受容体のみならずIL-2 も p 40tax により活性化され発現が起こる.これら $\mathrm{p} 40^{\operatorname{tax}}$ による IL-2 受容体, IL-2 の発現誘導は限られた T 細胞株のみ で認められている。これは，HTLV-I エンハンサーの 活性化とは明らかに異なり， p 40tax による遺伝子の発 現誘導には少なくとも 2 つ経路があることを示唆して いる. 最近の研究により, IL-2 受容体発現の p 40 tax による誘導は, 細胞の転写因子の 1 つである NF介したものであることが明らかとなった． $\mathrm{NF}-\kappa \mathrm{B}$ は当 初, 免疫グロブリンの軽鎖の $\kappa$ 鎖遺伝子のエンハンサー に結合する核因子として同定された。 p 40tax は SV 40 (simian virus 40) と HIV のエンハンサーも活性化す
る. この活性化も $\mathrm{NF}-\kappa \mathrm{B}$ によっている.

最近, p 40tax が細胞の癌遺伝子である $c$-fos をトラ ンスアクチベーションすることを見いだした. c-fos に 対応するウイルス遺伝子である $v$-fos は骨肉腫を誘発す る. $c$-fos は核因子の 1 つで, 同じく核型癌遺伝子であ る $c$-jun の産物 AP-1 と協同して細胞遺伝子の転写を 調節していると考えられている. p 40tax による $c$-fos の発現の変化が ATL 発症とどのように関連するかは今 後の課題である. p 40tax の発現ベクターを用いてトラ ンスジェニックマウスがつくられている.これらのマウ スにおいて発生した癌は今までのところ神経線維肉腫な ぞで， Т細胞の白血病化は報告されていない，ただし， p $40^{\operatorname{tax}}$ をもったトランスジェニックマウスは胸腺の萎 縮が認められて打り，興味がもたれる。

HTLV-I の pX 領域から p 40tax 以外にも核因子と なる p $27^{\mathrm{rex}}$ が産生される. p $27^{\mathrm{rex}}$ は核の中でも核小体 に局在する. 作用機構の詳細はまだはっきりしていない が，HTLV-I の mRNA のサブクラスの量を調節してい ると考えられる.この $\mathrm{p} 27^{\mathrm{rex}}$ もトランスに作用するも ので, シスの塩基配列として $3^{\prime}$ 側の LTR が要求される.

HIV のゲノム構造は HTLV-I よりさらに複雑であ る. 基本単位の遺伝子七ットのほかに, 少なくとも 6 種 類の遺伝子が知られている(4). そのうらの tat 遺伝子の 作用は, 現象が HTLV-I の p 40tax に似ている. 最終 的にウイルス産生を高めるトランスアクチベーターとし て働く. しかし, tat の標的配列は LTR 中のR 領域で あり，エンハンサーではない。また tat の作用は転写そ のものか, 転写後の過程に動くのか, いくつかの可能性 があげられている. rev (regulator of virion protein expression) 遺伝子の機能は HTLV-I の p $27^{\mathrm{rex}}$ に似 たトランスアクチベーターで, mRNA のサブクラスの 量を調節しているようである. rev 遺伝子産物があると ウイルスの構成タンパクを産生するための長い mRNA の量が多くなる.この調節は $r e v$ 遺伝子産物が mRNA の輸送にかかわっているためといわれている，HIV は 自分自身の LTR に働く産物をもら 1 つードしてい る. nef (negative-regulatory factor) と呼ばれるもの で, LTR 中の U 3 領域の $5^{\prime}$ 端に近い NRE (negative regulatory element) に作用して転写を抑制すると 
考えられている.

HTLV-I も HIV も動物レトロウイルスにみられない 複雑なゲノム構造とウイルス複製機構をもっている.こ れらウイルスのもつトランスアクチベーター遺伝子は本 来, ウイルスが宿主細胞の中で複製するのをバランスよ く制御するための機構であったかもしれない、それらの 機構が細胞側遺伝子の発現に影響し, 疾患にかかわって いる可能性が高い. したがって，これらウイルスのトラ
ンスアクチベーション機構を解明することは, 単にウイ ルス複製機構が明らかになるばかりでなく, 発症機構の 解明にも通じるものと期待される.

1）日沼頼夫：“新ウイルス物語”, 中央公論社, 1986.

2) F. Wong-Staal \& R. C. Gallo: Nature, 317, 395 (1985).

3) M. Yoshida \& M. Seiki : Ann. Rev. Immunol., 5, 541 (1987).

4) W. A. Haseltine \& F. Wong-Staal : Sci. Amer., 259, 34 (1988).

（中村正孝, 東北大学医学部細菌学教室)

\section{○、植物の細胞特異的フェレドキシン}

\section{葉肉, 維管束鞘細胞に異なるイソ蛋白質が存在}

現環境条件下では, 温帯や熱帯地域に生育する植物の 光合成効率の律速条件は, 大気炭酸ガス濃度が低いこと であると考えられている. $\mathrm{C}_{4}$ 植物は, 炭酸濃縮機構とし て働く $\mathrm{C}_{4}$ ジカルボン酸回路の獲得によって高能率の光 合成を営むよらになった一群の植物である.これらの植 物の炭酸固定反応は, 機能分化した 2 種の光合成細胞で ある葉肉細胞と維管束鞘細胞で共同して行なわれる. 大 気中の二酸化炭素は, まず葉肉細胞でリンゴ酸やアスパ ラギン酸のようなジカルボン酸として一次的に固定さ れ，これらが維管束鞘細胞に運ばれた後，そこで脱炭酸 反応により遊離するいわゆる濃縮された二酸化炭素がカ ルビン・ベンソンサイクルを経て再固定される.この葉 肉細胞と維管束鞘細胞の巧みな機能分担に負 $\mathrm{C}_{4}$ 光合 成経路の成り立ちは, 葉肉細胞で大気炭酸ガスを直接固 定する $\mathrm{C}_{3}$ 植物とは異なり, 関連酵素蛋白質の細胞特異 的発現の結果としてとらえることができる. また， $\mathrm{C}_{4}$ 植 物では炭酸同化系に加えて, 窒素や硫黄代謝系などでも 関連酵素の分布がこれら 2 種の光合成細胞で異なること が知られて扣り(1)， $\mathrm{C}_{4}$ 植物緑葉が営む種々の代謝反応や そのための酵素蛋白質の生合成は光合成細胞の分化と関 連づけて理解すべきものと思われる. しかし，炭酸同化 系を除いてはその具体像は明確になっていない.

炭素, 窒素, 硫黄の代謝は種々の酸化還元反応を必要 とするものであるが，これらの一連の代謝反応は，非へ ム鉄と無機硫黄を持った電子伝達蛋白質であるフェレド キシンが関与している過程を含んでいる. 最近, 代表的 な $\mathrm{C}_{4}$ 植物の一つであるトウモロュシに複数のフェレド
キシン分子種が存在し, 後に述べるようにこのフェレド キシン・イソ蛋白質の分布が葉肉細胞と維管束鞘細胞で 異なることが見いだされており，この現象がイソ蛋白質 の生理的意義解明の 系口になると 注目されている. ま た，他の $\mathrm{C}_{4}$ 植物（モロコシ，スーダングラス, パール ミレット）でも，同様にフェレドキシン・イソ蛋白質の 細胞特異的な分布が確認され, $\mathrm{C}_{4}$ 植物に普遍的な光合 成細胞の機能分化と関連した現象であると推察される.

トウモロコシの場合, 葉にはポリアクリルアミドゲル 電気泳動で移動度の異なる 4 種のフェレドキシン・イソ 蛋白質 (Fd I, II, III, IV) が存在し, このらち, Fd III と Fd IV は根や中胚軸のような非光合成器官にも認め られる. Fd I と Fd II は, 発芽成長段階で植物体の光合 成能獲得と呼応した増加様式を示して緑葉中での主要成 分となり, 光合成細胞内での代謝反応に直接関与してい るものと考えられる.さらに, 興味あることにこれらのイ ソ蛋白質は葉組織内で分布が互いに異なり, Fd I は葉 肉, 維管束鞘両細胞にクロロフィル量あたりほぼ等量ず つ, 一方 Fd II は維管束䩗細胞にのみ含まれている(2). フェレドキシンに依存した反応として, フェレドキシ ン-NADP ${ }^{+}$酸化還元酵素 $(\mathrm{FNR})$ による $\mathrm{NADP}^{+}$の光 還元，亜硝酸還元酵素 (NiR) による 亜硝酸からのア ンモニアの生成，亜硫酸還元酵素（SiR）による亜硫 酸からのサルファイドの生成, グルタミン酸 合成酵素 (GOGAT) によるグルタミンと 2-オキソグルタル酸か らのグルタミン酸の合成, チオレドキシン系を介した光 合成酵素の活性調節などが知られている，これらの反応 
は葉緑体内で起こり, 一般的には光化学系 I の作用で還 元されたフェレドキシンが電子供与体になると考えられ ている. 今話題にしている Fd I, Fd II の場合でも, 両 分子種はともに葉緑体ストロマに見いだされ，これらの フェレドキシン依存酵素類と相互作用できる細胞内区画 そ存在していることになる.したがって，単純に考学れ ば，Fd II と同様に維管束鞘細胞特異的に局在化するフ ェレドキシン依存酵素蛋白質があれば, これが Fd II と 関連した生理作用を営む可能性を示唆するものと思われ る.しかし、これまでに発表された文献や筆者ら自身の 解析によると, NiR や FNR は葉肉細胞に多く, SiR や GOGAT は両細胞に同程度存在すると結論され, 少 なくとも既知酵素類の中には維管束鞘細胞に特異的ある いは優先的に存在するものはないと思われる.

筆者らは, トゥモロコシ緑葉の葉肉, 維管束鞘両細胞 から別々に調製した葉緑体ストロマ画分を用いてフェレ ドキシンとアフィニティーを持つ蛋白質を探索した. そ の結果, GOGAT, FNR, NiR などフェレドキシンに関 与する既知酵素がアフィニティーを示したが，これらの 他に維管束鞘細胞葉緑体内にのみ存在するフェレドキシ ン結合蛋白質を見いだしている. この蛋白質は酸化還元 中心を持つことや他の $\mathrm{C}_{4}$ 植物にも存在することが明ら かになりつつあり，実際にフェレドキシンに関与したど のような反応を行なっているか, 今後の解明が待たれ る.
多くの高等植物 (主に $\mathrm{C}_{3}$ 植物) や藻類でフェレド キシンが複数のイソ蛋白質からなる例が報告されて拉 $\eta^{(3)}$, フェレドキシン依存反応がイソ蛋白質間で分業さ れているのではないかと推測されている. ラン藻の一種 Anabaena variabilis においては, 異質細胞には栄養細 胞に見られない特異的なフェレドキシン・イソ蛋白質が 存在し, ニトロゲナーゼの電子供与体として特殊化した 機能を持つ(4). そして, このイソ蛋白質遺伝子の発現が 栄養細胞から異質細胞への分化に伴う窒素固定酵素遺伝 子群の発現制御下に置かれていることが明らかにされて いる. 高等植物ではこのように実体が明確になっている 例はなく, 今回の $\mathrm{C}_{4}$ 植物緑葉内での細胞特異的なフェ レドキシン・イソ蛋白質の存在に関する知見は, 生体内 酸化還元反応におけるフェレドキシンを介した電子の分 配機構解明の糸口を提供するものと期待される. 現存の $\mathrm{C}_{4}$ 植物は, 複数の系統の $\mathrm{C}_{3}$ 植物がそれぞれ適応進化し て出現したものといわれている.この途上で獲得したで あろ 2 種類の光合成細胞, 葉肉細胞と維管束鞘細胞の 構築のための遺伝子発現機構が, 最近多くの研究者の注 目を集めているが，このような観点においてフェレドキ シンも良い研究対象になるものと思われる.

1) D. Schmutz \& C. Brunold : Plant Physiol., 64, 523 (1985).

2) Y. Kimata \& T. Hase : Plant Physiol., 89, 1193 (1989).

3) 新 勝光, 先浜直子: 生化学, 61(4), 251 (1989).

4) B. Schrautemeier \& H. Bohme: FEBS Lett., 184, 304 (1985).

（木股洋子, 長谷俊治, 名古屋大学農学部農芸化学科)

\section{冷血動物における甲状腺刺激木ルモン放出木ルモンの役割 メチル化アナログに強いホルモン作用}

甲状腺刺激ホルモン放出ホルモン (thyrotropin-releasing hormone, 以下 TRH) は, 1969 年 Schally らに より,また 1970 年 Guillemin らにより, それぞれプ タ，ヒツジの脳内視床下部から抽出・精製された. その 構造は pyroGlu-His-Pro $\cdot \mathrm{NH}_{2}$ と決定され, 化学合成品 そよりこのペプチドが脳下垂体前葉から主として甲状腺 刺激ホルモン (TSH) の, さらには成長ホルモン (GH), 乳腺刺激ホルモン (PRL), 濾胞刺激ホルモン $(\mathrm{FSH})$ な ど各種ホルモンの分泌を促進することが示された(1,2).

その後, このトリペプチドのアイントープラベル標品
および抗体を利用する微量定量法 (radioimmunoassay, RIA) により, TRH 様免疫反応物質 (IR-TRH) が視床 下部-脳下垂体系ばかりでなく中枢神経系および 内胚葉 由来の至るところに分布し，体温調節・食欲抑制など多 くの生理作用を示すことが明らかにされてきた ${ }^{(3)}$. さら に,この抗体を用いる免疫組織化学的手法やプレプロホ ルモン cDNAを用いるin situ hybridization によって, $\mathrm{TRH}$ の貯蔵部位や TRH 産生部位が証明されてきてい る.

IR-TRH は下等脊椎動物においても神経系に広く分 


\section{IR-TRH の濃度 (pg/mg 組織湿重量)}

\begin{tabular}{lccrl}
\hline & 大脳皮質 & 視床下部 & 脳下垂体 & 皮膚 \\
\hline ラット & 2 & 280 & 155 & \\
ヘビ & 338 & 564 & 865 & \\
カエル & 111 & 2,270 & $>5,000$ & 4,100 \\
サケ & 37 & 235 & 150 & \\
\hline
\end{tabular}

布し, 特に両棲類の脳には高濃度に存在している(表) ${ }^{(4)}$. 両棲類では皮膚に高濃度に存在することも報告されてい る. 無脊椎動物においてもマキガイの食道環神経節に, また, 植物ではアルファルファに存在するとされている.

しかし，TRH の生理作用については不明な点が多く， 両棲類および魚類においては PRL の放出を刺激すると 報告されているのみである(5). オタマジャクシからカエ ルへの変態およびヒラメの変態が, 脳下垂体一甲状腺系 のホルモンによって支配されていることが示されている が，これと TRH との関係はまだ解明されていない.ま た, サケは海水に入る直前に, 独特なしま模様をもつパ 一から銀白色のスモルトへと変化する. このスモルト化 への時期に甲状腺ホルモンが増加することが知られてい るがこれと TRH との関係もまた不明である.

一方, 脊椎動物の筋肉中には各種ヒスチジン関連化合 物, すなわち carnosine ( $\beta$-Ala-His, Car), anserine ( $\beta$-Ala-1-Me-His, Ans) および bálenine ( $\beta$-Ala-3$\mathrm{Me}-\mathrm{His}$ ， Bal）が多量に存在しており, サバ類・サケ類 にはAns が, ヘビ類・クジラ類には $\mathrm{Bal}$ が多く含まれ ている. Ans および Bal は遊離のヒスチジンが Car を 経てメチル化されると考它られるため, 同様にヒスチジ ンを含むぺプチド TRH もメチル化され，[1-Me-His $\left.{ }^{2}\right]$ TRH および [3-Me-His $\left.{ }^{2}\right] \mathrm{TRH}$ が存在すると考党られ る. 天然物としてのこれら TRH アナログの存在はまだ 知られていないが，合成の [3-Me-His $\left.{ }^{2}\right] T R H$ は TRH の約 10 倍強い生理活性を示すことが報告されている.

そこで, コイ・サケ・ミンククジラの脳から TRH 画 分を抽出し，高速液体クロマトグラフィー（HPLC）に よって分離し, RIA を用いて TRH アナログの検出を 試みたところ、コイでは〔1-Me-His $\left.{ }^{2}\right] \mathrm{TRH}$ の存在が示 された (図 $)^{(6)}$. サケ・ミンククジラでは哺乳類と同様の TRH が確認された. ついで, 大量のコイ脳から TRH 画分を抽出し，各種クロマトグラフィーにより分離・精

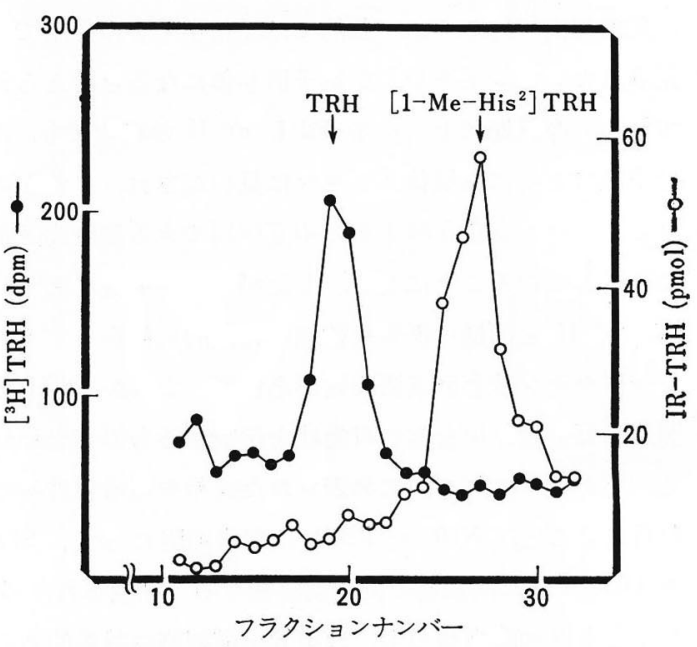

コイ脳 IR-TRH の逆相 HPLC による分離

$\left[{ }^{3} \mathrm{H}\right] \mathrm{TRH}$ は TRH の溶出位置確認のために添加

製を行なった後, 加水分解し PTC-アミノ酸誘導体とし てアミノ酸分析を行なったところ，[1-Me-His $\left.{ }^{2}\right] \mathrm{TRH}$ が確認された. さらに，コイ脳のホモジネートに TRH と $\left[{ }^{14} \mathrm{C}-\mathrm{CH}_{3}\right] \mathrm{S}-\mathrm{Ade}-\mathrm{Met}$ とを加光, $37^{\circ} \mathrm{C}, 20$ 分間イン キュベートしたところ, 微量ながら $\left[{ }^{14} \mathrm{C}-\mathrm{CH}_{3}\right][1-\mathrm{Me}-$ $\left.\mathrm{His}^{2}\right] \mathrm{TRH}$ が検出された.

ユイ以外の魚類および他の下等脊椎動物からも TRH アナログが検出される可能性が示唆される.これは, こ れまで両棲類・魚類で PRL の放出促進しか報告されて いなかった TRH の生理作用を，TRH アナログないし は両者の作用によって説明することができる可能性を意 味している.

TRH も多くの脳下垂体ペプチドホルモンと同様に, 前駆体ホルモンがプロセシングされて生じることが知ら れている.このメチル化がプロホルモンで行なわれるの か TRH になってから行なわれるのか, その機構も今の ところ明らかではない。この酵素を単離してその性質を 調べることによって，さらに生理作用の解明が進むもの と思われる. しかしながら, 生体内には 3 つの TRH 分 解酵素, すなわち TRH amidase, pyroglutamyl amino peptidase, imidopeptidase が存在し，異化代謝速度は 非常に速い $\left(37^{\circ} \mathrm{C}, 30\right.$ 分間でほぽ分解).

以上, 哺乳類の視床下部から発見され, 単純なトリペ プチドの 化学構造ながら多彩な 生理作用を示す TRH 
は，下等脊椎動物においてもさらに多様な生理作用を示 すことが期待されておりこのメチル化 TRH の存在が その生理作用解明の一助になるものと思われる。

1）柳沢 忠：“ホルモンハンドブック”，日本比較内分泌学会 編, 南江堂, 1988, p. 8.

2) E. C. Griffiths \& G. W. Bennett : "Thyrotropin-Releasing Hormone", Raven Press, New York, 1983.

3) C. Prasad: "Handbook of Neurochemistry", ed. by A.
Lajtha, Vol.8, Plenum, 1985, p. 175.

4) I. M. D. Jackson \& S. Reichlin : Endocrinology, 95, 854 (1974).

5) S. Kikuyama, K. Koiwai, M. Sakai, T. Seki \& T. Yanagisawa : "Kyoto Prolactin Conference Monograph", Vol.2, ed. by K. Hoshino, Kyoto Univ. Fac. Med., 1987, p. 123.

6) T. Yanagisawa \& K. Hamano:Fed. Proc., 46, 2252 (1987).

（柳沢 忠, 宇都宮大学農学部)

\section{キノコに学びキノコを超えるリグニン分解人工酵素 リグニンペルオキシダーゼとバイオミメティック触媒系}

ニューバイオテクノロジーの進展に伴い, 生体（系） を模倣するバイオミメティックアプローチにも大きな関 心が寄せられている. その例も酵素類似機能をもつ人工 酵素に始まりロボットや人工知脳に至るまで，千差万別 である、林産分野では, 最近の紙パルプ産業へのバイテ ク導入と関連して, リグニンを分解するキノコ（白色腐 朽型担子菌類）に関する研究が注目されている。ここで は，その動向と筆者らが開発した新しい人工酵素（リグ ニナーゼミメティック触媒) 系の応用例について紹介す る.

白ぐされ菌と呼ばれるキノコがリグニンを分解すると きの基本的な特徵は次のようにまとめられる.

(1) 木材の多糖類がエネルギー源として必要である.

(2) グルコース (C-源) やアミノ酸 (N-源) が欠乏し た栄養飢餓の下ではじめてリグニン分解力が活性化され る.

(3)、リグニン分解酵素（ペルオキシダーゼの一種）は
昔, 樹木はリグニンドラゴンをその傭兵としてつくり出 し, 森林要塞の構築に成功. キノコは逆に, リグニン分 解酵素なる秘密兵器 (スーパーガン) を発明し，リグニ ン砦の攻略に成功した，と想像しよう.

面白いことに, この種のリグニン退治の名人たちは奇 妙な性癖をるつ. 食糧が豊かで満腹時にはリグニン退治 をせず，栄養飢餓（C, N-源欠乏）下ではじめて 鉄砲か ついでリグニン退治の遠征に出かける（リグニン分解酵 素の活性化). しかて, 腹が減っては戦ができず，もっと 白米（セルロース）のおにぎりをたくさん持ってこいだ の, やれ弾薬（過酸化水素）が足りないだのと，文句を 言いつつも一応りグニンを退治する.ドラゴン一匹倒す と，それで十分とし，白米のセルロースをもりもり食 ベ，満腹になると，スーパーガンを放棄し，しばらくは 休戦 (酵素活性の消失).きわめてハングリー精神に欠 けた代物なのだ.

ちなみに, リグニン分解菌の中で世界的な人気を誇る 過酸化水素を使ってリグニンを攻 撃, 分解している.

リグニンは複雑なフェノール性高 分子(1)で，木材中では細胞をくっつ ける接着剤の役割をしているが，キ ノコに食われるとばらばらに解体さ れ, 多糖類が利用可能な状態とな る.そこで、リグニンとキノコとの 相互作用を一枚のマンガ (右図) を 使って解説することを沶許し願いた い.さし絵が示すように，太古の

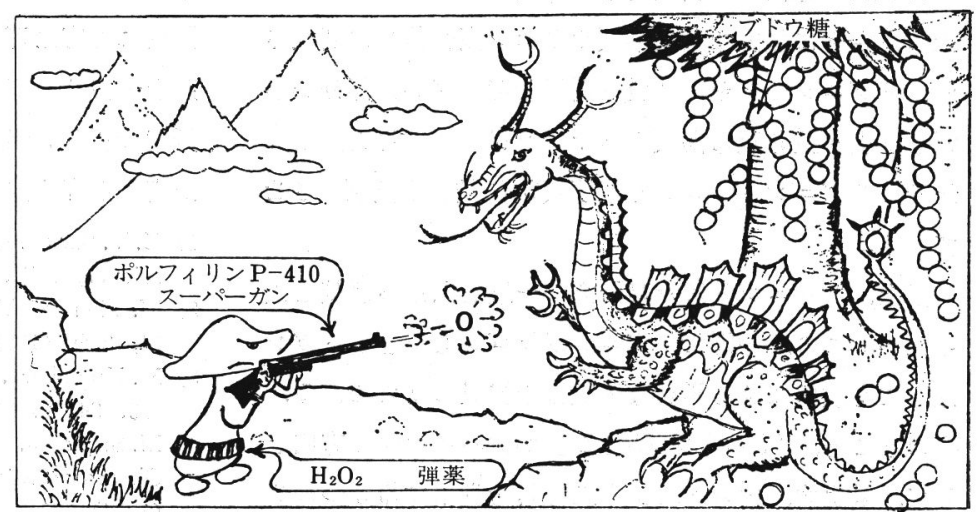

キノコとリグニンドラコンとの合戦 
のはシイタケ菌. 日本の伝統技術が生んだ文字どおり 「ドル箱」スターである.

しかし，白ぐされ菌の変わり者でスウェーデン生まれ の Sporotrichum pulverulentum をして白米には手をつ けず麦めし(へミセルロース) だけでリグニン退治がで きる変異株に改造したのは，同国の Eriksson ら (1975 年）である. 勇壮果敢な「バイキング」Cel 44 株の登場 である. 当初, これが紙パルプ業界 No. 1 のスターダム にのし上った感があった．なぜなら, Cel 44 株はセルラ 一ゼを欠損していてセルロースの分解能力を欠損してい るため, バイオパルプ製造に好都合だからである.

第二のスターは，血統は前者と同じなのに，どうした ことか名付親はアメリカ人, アメリカ育ちの Phanerochaete chrysosporium 菌. アリゾナ州出身でリグニン退 治の早射ちガンマンといったところ.この達人からス ーパーガンを奪い取り（1983 年），その仕掛けを解明 したのはアメリカの研究グループ (Kirk らと Gold ら) ${ }^{(2,3)}$ ，それより早く，その人工酵素モデルを考案し， 酵素の代わりにポルフィリン類がスーパーガンに匹敵す る威力を持つことを最初に証明したのが筆者ら ${ }^{(4)}$ であ る. 翌年, 日，米，英，三国が先を争って，一電子移動 酸化理論を発表することとなった(5 7).

つまりキノコが発明したスーパーガンは「ウインチ エスター型」や「レミントン型」でもなく「ポルフィリ ン型ショットガン」であると証明された．この酵素は, ヘモグロビンやチトクローム P-450 などと同類のへム タンパク質, ペルオキシダーゼであった.

リグニン退治に必要な過酸化水素はこのポルフィリン 上で,ささに強力な酸化剈（オキ七ン複合体）に変換さ れ, リグニンのアキレス腱（電子密度の高い）部分から 電子を引き抜き致命傷（カチオンラジカルの生成）を負 わせ、リグニンドラゴンを崩壊（C-C 結合を開裂）させ ている.

以上, リグニン分解酵素研究の一端を伝える漫談とな ったが, この地球圏でリグニンドラゴンをショットガン なしでも攻撃できる勇猛な菌類は未発見のままである. 今のところ, 紙パルプ 産業に生かすパイテクの方向と して，微生物，酵素および人工酵素を利用する 3 つの プローチが進展しているが，いずれる一長一短あり，応
用は難しい。

人間は木材を $200^{\circ} \mathrm{C}$ 近い温度で蒸惹, パルプ漂白など の後処理にも手を焼いているのが現状. キノコはスマー トにも室温でリグニン退治をやっている．ここに生体触 媒の秘密があり，バイテクによる省エネルギー，資源 と環境問題のブレイクスルーを狙う妙味がある. 実際, Eriksson は Cel 44 株でパルプ用チップを数\%脱リグニ ンすれば 20〜30\% の省エネが可能と世界に宣伝した が，実用化の点では後退している．Kirk らの見いだし たリグニンペルオキシダーゼも in vitro 系ではリグニン を完全分解できず，今や in vivo 系の脱重合因子の探索 などの基礎研究に再び注意が向けられるようになった。

筆者らの発見した「ポルフィリンショットガン法」 は，微生物や酵素よりも経済的で実戦に向いているとこ ろがセールスポイントであるが, 安定性について問題が あった．そこで，これに代わる一電子移動触媒を探査し ていたが，最近， $\mathrm{Mn}(\mathrm{N})$ 活性種を用いる新しいリグ ニナーゼミメティック触媒系を開発することに成功し た(8). すなわち，微量のコバルト酢酸と過剩の過酢酸の 存在下で, $\mathrm{Mn}(\mathrm{II})$ 酢酸を $\mathrm{Mn}(\mathrm{N})$ 種に変換し, リグニ ンモデル二量体の $\mathrm{C}_{\alpha}-\mathrm{C}_{\beta}$ 結合開裂を室温で達成した. かつ, 未漂白クラフトパルプ（白色度 $35 \%$ ）は, $50^{\circ} \mathrm{C}$, 30 分間で白色度 $80 \%$ 以上に漂白され, 従来の塩素系漂 白度に匹敵する成果が得られた。

昨年末，軌を一にして，Mnイオンを活用する新しい リグニンペルオキシダーゼ系が報告されたが(9), Mn （N）種の利用についてはまったく言及されていない.

筆者らの開発したバイオミメティック触媒系は, パルプ 漂白にも応用可能であり, 実用化の点でも微生物と酵素 系を一歩リードした感がある、本法は, 紙パプ産業界 懸案の新しい無塩素漂白法でもあり, 河川と海洋を塩素 公害から守る技術として発展することを期待している.

1) K. V. Sarkanen \& C. H. Ludwig : "Lignins", Wiley Interscience, 1971, p. 916.

2) M. Tien \& T. K. Kirk : Proc. Natl. Acad. Sci. USA, 81,2280 (1984).

3) M. Kuwahara, J. K. Glenn \& M. H. Gold : FEBS Lett., 169, 247 (1984).

4) M. Shimada, T. Habe, T. Umezawa, T. Higuchi \& T. Okamoto: Biochem. Biophys. Res. Commun., 122, 1247 (1984).

5) P. J. Kersten, M. Tien, B. Kalyanaraman \& T. K. Kirk : 
J. Biol. Chem., 260, 2609 (1985).

6) T. Habe, M. Shimada, T. Okamoto, B. Panijpan \& T. Higuchi : J.Chem. Soc. Chem. Commun., 1985, 3123.

7) H. E. Schoemaker, P. J. Harvey, R. M. Bowen \& J. M. Palmer : FEBS Lett., 183, 7 (1985).

8) 島田幹夫, 中川麻理子, 服部武文, 桶口隆昌 : 第 39 回日本
木材学会大会要旨集 (1989).

9) I. T. Forrester, A. C. Grabski, R. R. Burges \& G. F. Leatham: Biochem. Biophys. Res. Commun., 157, 992 (1988).

\section{機能性綟蛋白質の利用はごこまで進んでいるか 医用膜, 酵素・抗体固定化の担体など多くの可能性}

綟は優れた風合いと優雅な光沢を持ら, 染色性, 吸放 湿性にも優れた特性を発揮するため, 過去数千年にわた って専ら高級衣料素材として利用されてきた。このよう な絹固有の優れた物理・化学的特性の発現機構を明らか にするため，あるいは昆虫由来の生体高分子の構造に対 する科学的興味から，絹蛋白質の構造と物性に関して古 くから研究が進められてきた．現在のところ，未だ結晶 構造あるいは高次構造などの全容を明らかにするには至 っていないが，特異な構造に基づいて生ずる多様な機能 特性が解明されつつある. 衣料素材以外にも各種産業分 野での用途開発が期待されるようになり，主としてバイ オ材料など非衣料分野での用途開発が最近積極的に進め られている.

綟蛋白質は, アミノ酸組成と特徴ある高次構造によっ て発現する多様な機能と優れた理化学特性を持ってお り, 虫体を通じて純粋な形で, 多量に, 乙か子随時生産 することが可能である。 また，調製方法を適宜選ぶこ とで, 絹蛋白質は膜状, 粉末状, 繊維状, あるいは溶液 状などに形を自由に変えることができる.ささらに，絹素 材は生体適合性に富む良質な蛋白質であることから，そ の利用に深い関心が寄せられるようになった. 最近のバ イオテクノロジーや蛋白工学の発展に触発された形で,

亘由来の絧蛋白質の機能性を人為的にデザインする技術 の開発研究も進んでおり, 付加価值の高い機能性新素材 として綟の新しい利用法が注目されている.

絹系は，綟系本体であるフィブロイン繊維を膠状の七 リシンが覆った形態をとって構成されている. 絹フィブ ロインと綟セリシンとは化学組成のまったく異なる蛋白 質であり，こうした絹蛋白質は亘体内の綟糸腺内の液状 物質からも，あるいは製糸の副産物であるくずの䒽系を 中性塩で溶解した水溶液からも調製できる.
絹蛋白質が各種の病原微生物や微粒子病原虫などをス ライドグラスに付着させるための接着剤として利用でき ることが最近の研究で明らかになった。この方法をラテ ックス法に応用した場合には，供試原虫を綟の貼付剂面 に付着固定させた後，原虫に対する抗体感作担体を作用 させてその㠜集反応を顕微鏡で観察することにより供試 原虫の識別・同定が可能である.なお，この方法による と対象微生物をいったん固定すると抗体感作担体を反復 処理することができるので，同一の個体についての連続 観察が可能である.

箕浦ら ${ }^{(1)}$ は，マウス由来の瀻維芽細胞 L 929 を用い， 試料膜の表面上に $10 \%$ の仔ウシ血清を含んだ細胞浮遊 液 (約 10 万 $/ \mathrm{ml}$ ) を加兄, 所定時間培養して綟フィブロ イン膜上での細胞の付着・増殖の実験を試みた，その結 果, 絹フィブロインは, 従来細胞の付着性が良好である と言われているコラーゲンに匹敵する優れた細胞付着・ 増殖能力を持つことが確かめられた.

末梢静脈内試料被膜系留置法により, 綟フィブロイン の血液適合性が最近調べられた ${ }^{(2)} .14$ 日間留置後の結果 によると，絹フィブロイン膜は良好な血液適合性を示 し, 試料表面では血栓の形成が抑制されることが確かめ られた．絹蛋白質は物質透過膜の素材としても優れてい る. 筆者ら ${ }^{(3)}$ は, 湿潤状態に预ける絹フィブロイン膜の 酸素透過性を検討し, 低含水率の領域において子綟フィ ブロインは良好な酸素透過性を示すことを実験的に確認 した. 同一含水率の 2 -ヒドロキシェチルメタクリレート 膜の酸素透過係数と同等あるいは若干低い数值を示すこ とから, 絹フィブロイン膜は酸素透過を必要条件とする コンタクトレンズ素材をはじめとする各種の医用膜への 応用が可能であろうと考穴られる.ささに, 絹フィブロ イン膜は可視光領域付近でも透過率が $98 \%$ であること 
から，無色透明度の高い試料膜であると同時に，水蒸気 の透過性も良好である。こうした物理的機能特性を利用 することで，絹フィブロインは生体の自己細胞が増殖す るまでの間，体液の漏出を防ぎ細菌その他の侵入を抑え るための人工皮㦒素材としても利用できる可能性を秘め ている.

絹フィブロイン成膜条件と膜界面物性との相関性の究 明とイオンの透過珄に関する研究も行なわれている。さ らに，絹蛋白質膜の物質透過性の特幑を活用した利用例 の一つに, パーペーパレーションによる水ーエタノール の分離の検討もなされて扮り，広津らにより，膜厚が約 $20 \mu \mathrm{m}$ 以上となると水の選択透過性が現われること， 厚さとともに選抧性が増加し透過速度が減少することが 明らかにされた。

絹蛋白質を構成するアミノ酸には反応性の高い分子側 鎖を有するものがある，こうした部分を利用して，ある いは絹素材の物理的またはイオン的結合力を活用して， 絹蛋白質を酵素固定化担体と乙て利用しようとする試み が市る. 朝倉 ${ }^{(4)}$ は，包括法によりグルコースオキシダー ゼを綟フィブロイン中に含有させた場合，試料膜中の酵 素活性が遊離酵素の場合と法とんど変わらない膜が得ら れたことがら, 酵素含有膜がグルコースセンサーとして 利用できることを明らかにした．担体に綟フィブロイン を用いることで，活性が遊離酵素の場合とほとんど変わ らない膜が得られること，醳素の活性の $\mathrm{pH}$ 領域が広 くなり膜の温度安定性も向上すること，膜中の酵素活性 は1 カ以上経過しても低下しないことが確認された。 また，担体として綟の代わりにゼラチンを用いた場合の 酵素活性は，絹を用いた場合に比べて酵素の固定化が不 十分であり, 安定性の点に领いても劣っているとされて いる. 一方, こうした上記の酵素の物理的包含法に対し て，絹の活性基と酵素とを化学的共有結合によって固定 化する方法子試みられている. 絹の分子側鎖のうち反応 性の高いチロシン側鎖部分にジアゾ法を適用したもの, あるいはカルボニル基部分にアジド法を適用してアルカ リホスファターゼ，リボヌクレアーゼなどの酵素固定を 行なった実験例が知られている。こうした実証例は，反 応性に富んざ絹蛋白質がバイオ七ンサーあるいはバイオ リアクターの担体として実用化できる可能性の高いこと
を示唆するものであるら．

衣料用上，䋐維素材としてむったく用いられていない 絹セリシンには絹フィブロインの場合よりも反応性に富 んだチロシンなどのアミノ酸が多く含まれている、した がって，担体結合法によりこうした反応性部分に酵素を 結合させることにより，物理的機能性を生かした絹セリ シンの有效利用技術が開発できるものと期待できる.こ らした目的で絹フィブロインのアミノ酸側鎖部分のら ら，チロシンの側鎖部分をスピンラベルし，ラベル位置 の分子運動性が朝倉ら (5)により検討された。 その結果， 試料膜は高い熱安定性を示すこと, 試料分子のスピンラ ベルを施しても試料本来の構造が保持されることが実証 されたささらに筆者ら゙はは，今後綟蛋白質の有效利用を 図るには絹の試料分子と酵素とがどのよらな相互作用を 有するかを分子レベルで十分検討しておくことが重要と 考光，可塑剤としてポリビニールアルコール (PVA) あ るいはポりビニールピロリドン (PVP) を用いて作製し た絹セリシン膜にカルボニル基, 水酸基, アミノ基, アミ ド基をそれぞれ有する 4 種類のスピンプローブ分子を包 括させた試料膜の ESR スペトルを測定し，含水状態で のスピンプローブ分子の運動性あるいは各官能基と膜構 成分子間の相互作用の解析を試みた. スピンプローブ分 子の運動性は，PVA 膜ならびに絹セリシン/PVA のブ レンド膜のほうが, PVP ならびに絹セリシン/PVP ブ レンド膜よりる特異的に低下した：このことから，七リ シンの分子側鎖 とスピンプローブ分子の $\mathrm{C}=\mathrm{O}\left(\mathrm{NH}_{2}\right)$ との間で水素結合が形成される可能性が高いものと推定 した。こうした基礎的知見は，今後絹蛋白質を人工的に デザインして酵素，医薬品などを包含，固定化させる上 で，絹分子の反応部位を特定し，化学修飾するための知 見を得る上で重要な情報を与えるものだある。

鐘紡では, 絹フィブロイン膜の表面に抗体を包括国定 化させることにより，酵素免疫測定を可能にする技術を 開発した，抗体の固定化状態は良好で，保存安定性に優 れ，かつ非特異的吸着による定量阻害，分離阻害も少な いことから，免疫化学的測定が可能であるとされている. このように，綃フィブロインは，試料マトリックス中に 抗体を包含することで，様々な診断のシステムづくりの 上でも役立つ貴重な生体蛋白質であるとるいえよう， 
今後, 絹蛋白質の物理的特性を利用し, 付加価值の高 い新素材の研究開発をさらに進展させるためには，絹蛋 白質の構造と機能との相関をさらに引き続き解析し，新 たな利用開発に関する基礎的情報を豊がすることが必 要である，そのことにより，絹蛋白質が持つ新たな機能 性が見いだされ，衣料素材としてはもとより，工業資 材，医療資材として綟を利用する技術が開発できるもの と考党られる。
1) 箕浦憲彦, 相羽誠一, 冨士原行彦, 田口和宏, 塚田益裕 : 第 5 回生体繊維と生医学材料に関するシンポジウム講演要旨集, 3C01 (1988).

2）野一色泰晴, 伊藤 啓, 宮本武明, 河完 - 植 : 緘維学会シ ソポジウム予稿集, 3C15 (1988).

3）箕浦憲彦, 塚田益裕, 奈倉正宣：第 3 回膜一その基礎科学々 技術一に関するシンポジウム講演要旨集, 3A21 (1987).

4) 朝倉哲郎：パイオインダストリー, 4, 878 (1987).

5）朝倉哲郎，吉水広明，塚田益裕，瀬戸山幸一，光田慶一：緘 学誌, 43, 335 (1987).

6）塚田益裕, 朝倉哲郎, 吉水広明：日虫雑，57，46（1988).

（塚田益裕, 農林水産省虫系・昆虫農業技術研究所）

\section{イネ $\alpha$-アミラーゼの分泌}

\section{細胞内輸送過程で糖鎖修飾。環境要因による変動に興味}

高等植物細胞に打将る $\alpha$-アミラーゼの分泌に関する 研究は，主にイネ，オオムギおよびュムギの種子を用い て行なわれてきだ、発芽イネ種子に扔いては，胚盤上 皮細胞が主要な $\alpha$ アアミラーゼ産生組織であること, 括よ

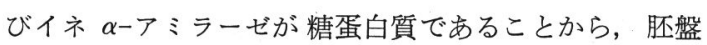
組織を用いて分泌性糖蛋白質としての $\alpha$-アミラーゼの

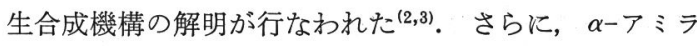
一ゼの分泌に及ぼす $\mathrm{Ca}^{2+}$ の効果が調べられ, $\mathrm{Ca}^{2+}$ が $\alpha-$ アラーゼ分泌を促進することが明らかになっ た ${ }^{(4,5)}$. 最近では, イネ液体培養細胞系を用いた $\alpha$-アミ ラーゼ分泌の研究が活発に行なわれるようになり， $\alpha$-ア ミラーゼの細胞内輸送機構などに関して興味深い事実が 見いだされている。

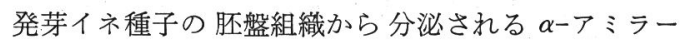
ゼは, アスパラギン結合型糖鎖を持つ典型的な分泌性糖 蛋白質である。 $\alpha$-アミラーゼの生合成については, 粗面 小胞体 (rER) そ括いてポリペプチド鎖の伸長と同時に コア糖鎖の導入が行なわれることが明らかになってい る.しかし，その細胞内輸送のメカニズムは泀とんぞわ かっていなかった。 そこで, $\alpha$ ーアミラーゼの細胞内輸送 機構が糖鎖合成の観点から追求され，発芽イネ種子から 精製された $\alpha$ ーアミラーゼの糖鎖構造を Endo- $\beta-N$-acetylglucosaminidase $\mathrm{H}$ (Endo- $\beta-\mathrm{H})$ を用いて調べてみ た結果, Endo- $\beta-\mathrm{H}$ の糖鎖切断作用に対して耐性 (R) 型と感受性 $(S)$ 型の 2 つ分子種がほぼ同じ割合で存 在していることがわかった. Endo- $\beta-\mathrm{H}$ は，高マンノー ス型および混合型糖鎖を根元から切断するが, 複合型に
はまったく作用しないといら反応特異性を持つ酵素であ り，アスパラギン結合型糖鎖の構造を識別するのに広く 用いられているものである.

肧盤組織から分泌された $\alpha$ オミラーゼについても， 糖鎖構造が Endo- $\beta-\mathrm{H}$ によって解析された，胚盤組織 を $\mathrm{Tris}^{-\mathrm{Ca}^{2+}}$ 溶液でインキュベートすると， $\mathrm{R}$ 型と $\mathrm{S}$ 型 $\alpha$ アアミラーゼの分泌が観察された，rER で合成される $\alpha$-フミラーゼは $\mathrm{S}$ 型であり，したがって $\mathrm{R}$ 型は細胞内輸 送中に糖鎖修飾を受けたものと考兄られる.ささら， R 型と $\mathrm{S}$ 型分子の分泌は, 分泌阻害剂モネンシン, $\mathrm{Ca}^{2+}$ や温度などによってそれぞれ異なる影響を受けるという 結果が得られた ${ }^{(6)}$. 動物細胞では分泌性糖蛋白質の糖鎖 形成機構に関して膨大な研究分行なわれており, rER で 導入されたコア糖鎖がゴルジ複合体において高マンノー ス型から複合型に修飾されることが明らかにされてい る.これらの実験結果から, 肧盤組織に拈ける $\alpha-$ ア ラーゼの細胞内輸送には, one-route model と tworoute model の 2 つの可能性が考光られたのである(7). one-route model とは, ER $\rightarrow$ ゴルジ複合体 $\rightarrow$ 細胞膜と いら経路のモデルであり， two-route model とは， $\mathrm{ER} \rightarrow$ ゴルジ複合体 $\rightarrow$ 細胞膜経路と平行して $\mathrm{ER} \rightarrow$ 細 胞膜経路が存在しているといらモデルである.

林らは，発芽イネ種子（農林 14 号）の胚組織に由来

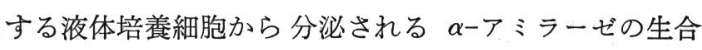
成と細胞内輸送の研究を進めている(8): この液体培養細

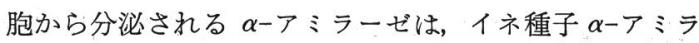
一ゼのアイソザイム $\mathrm{A}+\mathrm{B}$ と分子量および等電点が同 
じで，しかも免疫化学的にも区別できないものであっ た. Endo- $\beta-\mathrm{H}$ を用いた糖鎖構造解析の結果, 培地（改 良 R-2 培地）中にはR 型 $\alpha-$ アミラーゼのみが分泌され ることが明らかとなった．ところが，培地に Tris を加 えたところ， $\mathrm{R}$ 型と $\mathrm{S}$ 型分子が 分泌されるようになっ た．そこで，それぞれの条件で分泌された $\alpha$ そアミラー ゼの糖鎖を調べた結果， 前者の条件においては， N-フ セチルラクトサミン型桾鎖のみ，後者では $N$-アセチル ラクトサミン型とオリゴマンノース型糖鎖が存在してい ることが明らかになった．この結果は，Endo- $\beta-H$ で得 られた結果とよく一致している。胚盤組織においても， 改良 R-2 培地ではR 型 $\alpha-$ アミラーゼのみ分泌され，高 濃度の Tris 存在下ではS 型分子の分泌が観察された。 さらに, $\alpha$-アミラーゼの糖鎖形成機構を解析するため, ゴルジ複合体に局在しているマンノシダーゼ $1 \mathrm{~A} / \mathrm{B}$ の 阻害剤である 1-デオキシマンノジリマイシン (dMM) の効果を調べたところ，液体培養細胞に d MM を加兄 ると， $\alpha$ ーアミラーゼ糖鎖の修飾が完全に抑制され， S 型 分子が分泌されることがわかった。

動物細胞でも，Tris などの弱塩基性アミン類の存在 下では，本来複合型糖鎖を持つ分泌性糖蛋白質が，高、 ンノース型糖鎖を持ったまま分必されてしまうことが報 告されている ${ }^{(9)}$. 弱塩基性アミン類の糖鎖修飾の阻害作 用は, ゴルジ複合体のトランスコンパートメントの $\mathrm{pH}$ を上昇させ，そこに局在する糖鎖修飾酵素の活性を低下

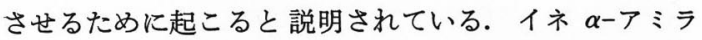
一ゼに及ぽす Tris 拈よび d M 果が，動物細胞の分泌性糖蛋白質のそれと一致すること

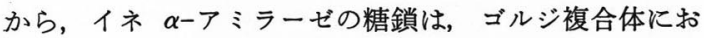
いて高マンノース型から複合型に变換されることが強く 示唆されたわけである.

これらの結果から林らは，胚盤組織で見られた $\mathrm{R}$ 型と $\mathrm{S}$ 型 $\alpha$-アミラーゼの分泌は Tris- $\mathrm{Ca}^{2+}$ の効果によるも

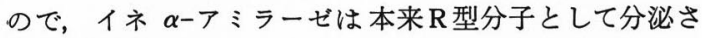
れるものであり，したがってイネ $\alpha$ アミラーゼの細胞 内輸送機構としては one-route model がより妥当であ ると結論している，それでは，なぜ発芽イネ種子から精 製された $\alpha$-アミラーゼに $\mathrm{R}$ 型とほぼ等量の $\mathrm{S}$ 型が含ま れているのかという疑問が残る.これについては，細胞
内の合成途中の中間体が 含まれていることおよび $\alpha$ アミラーゼの糖鎖修飾が, Tris, $\mathrm{Ca}^{2+}$ や温度環境などに 影響されることから, 発芽時の何らかの要因によって糖 鎖修飾が 抑制されたために $\alpha$-アミラーゼの一部が $\mathrm{S}$ 型 のまま肧乳中に分泌されたといら可能性が考兄られてい る. いずれにしても，イネ液体培養細胞における $\alpha$ ミラーゼ分泌は, 高等植物細胞の糖蛋白質の分泌機構を 解明するための優れたモデル系と考えられ，今後の研究 によって多くの新しい知見がもたらされるものと期待さ れる.

現在, 筆者らの研究室では, イネ種子（日本海）の液 体培養細胞に打けるアミラーゼアイソザイムの分泌に関 する研究を行なっている.この培養細胞から分泌される アミラーゼには，発芽イネ種子の $A+B$ に相当する低等 電点グループ $(\mathrm{p} I$ 4.6〜4.9) とともに, 高等電点グルー プ（ $\mathrm{p} I$ 5.5 5.9） のアイソザイムが多量に含まれてい る. 高等電点グループのアイソザイムがどのような特異 性を持つアミラーゼなのかまだ不明であるが，これらは 発芽イネ種子では量的に少なく，また林らが用いている 農林 14 号の培養細胞においてはほとんど見られないも のである、なぜ，高等電点グループのアイソザイムが筆 者らの培養細胞で多量に生成されるようになったのか？ 高等電点グループの活性発現を誘発する要因や発現機構 の解明が今後の研究課題である.

1) T. Akazawa, T. Mitsui \& M. Hayashi : in "The Biochemistry of Plants", Vol.14, Academic Press, New York, 1988 , p. 465.

2) K. Okamoto \& T. Akazawa : Plant Physiol., 63, 336 (1979).

3) S. Miyata \& T. Akazawa : J. Cell Biol., 96, 802 (1983).

4) T. Mitsui, J. T. Christeller, I. Hara-Nishimura \& T. Akazawa : Plant Physiol., 75, 21 (1984).

5) M. Hayashi, T. Mitsui \& T. Akazawa : Plant Physiol. Biochem., 27, (1989) in press.

6) 三ツ井敏明：蛋白質 核酸酵素別冊，30 号，p. 386.

7) T. Akazawa \& I. Hara-Nishimura : Ann. Rev. Plant Physiol., 36, 441 (1985).

8) M. Hayashi, A. Turu, N. Takahashi \& T. Akazawa : 投 稿中.

9) K. Oda, S. Ogata, Y. Koriyama, E. Yamada, K. Mifune \& Y. Ikehara : J. Biol. Chem., 263, 12576 (1988).

(三ツ井敏明, 新潟大学農学部農芸化学科) 